\title{
Aspek Stilistika dalam Antologi Puisi Melipat Jarak Karya Sapardi Djoko Damono dan Pemanfaatannya sebagai Materi Pengayaan Sastra
}

\author{
Abdul Mukhlis ${ }^{1)}$, Teguh Supriyanto ${ }^{2)}$, dan Mimi Mulyani ${ }^{3)}$ \\ 1) Prodi Pendidikan Bahasa dan Sastra Indonesia, Pascasarjana, Universitas Negeri Semarang \\ E-mail: abdulmukhlis75@yahoo.co.id \\ ${ }^{2)}$ Universitas Negeri Semarang \\ E-mail:teguhsp@mail.unnes.ac.id \\ ${ }^{3)}$ Universitas Negeri Semarang \\ E-mail: mimimulyani62@mail.unnes.ac.id
}

\begin{abstract}
Abstrak. Penelitian stilistika ini bertujuan untuk (1) mendeskripsikan bentuk bahasa figuratif yang dominan dalam antologi puisi Melipat Jarak karya Sapardi Djoko Damono, (2) mendeskripsikan bentuk citraan yang dominan yang digunakan dalam antologi puisi Melipat Jarak karya Sapardi Djoko Damono, (3) memaparkan pemanfataan aspek stilistika yang ada dalam antologi puisi Melipat Jarak karya Sapardi Djoko Damono sebagai materi pengayaan sastra di SMA kelas X. Penelitian ini menggunakan stilistika sebagai alat pendekatannya. Metode analisis yang digunakan adalah deskriptif analisis semiotik melalui pembacaan heuristik dan hermeneutik untuk mengungkap aspek stilistika dan analisis komparatif untuk memaparkan pemanfaatan aspek stilistika dengan materi pengayaan sastra. Hasil penelitian berdasarkan analisis data menunjukkan (1) bahasa figuratif yang ditemukan antara lain majas 60 data dan idiom 1 data, majas yang dominan yakni personifikasi 18 data (30\%), simile 11 data $(18,5 \%)$, dan metafora 10 data $(16,65 \%)$, (2) data citraan yang ditemukan sebanyak 99 data. Citraan yang dominan yaitu citraan gerak 33 data (33\%), pendengaran 29 data (29\%), dan penglihatan 22 data (22\%), dan (3) pemanfaatan aspek bahasa figuratif dan citraan dalam antologi puisi Melipat Jarak sebagai materi pengayaan sastra di SMA kelas X terbagi dalam dua kegiatan, yakni eksploratori dan keterampilan proses.
\end{abstract}

Kata Kunci: bahasa figuratif; citraan; pengayaan sastra

\section{PENDAHULUAN}

Puisi merupakan salah satu genre karya sastra yang paling awal muncul. Kemunculan salah satu genre karya sastra ini mengalami perkembangan sesuai dengan masanya. Meskipun begitu, ada satu hal yang tidak bisa terganti sejak awal kemunculan puisi hingga sekarang, yakni bahasa. Bahasa adalah medium utama sebuah puisi. Akan tetapi, bahasa dalam puisi tidaklah sama dengan bahasa yang digunakan dalam keseharian. Bahasa sastra mengalami penyimpangan dalam hal penerapannya. Penyimpangan-penyimpangan tersebut memang sengaja dilakukan oleh penyair dalam rangka mencapai keestetikan karya sastra (Al-Ma'ruf, 2009).

Secara umum, cabang kajian ilmu yang fokus pada eksplorasi dan manipulasi bahasa sehingga tercipta keestetikan adalah stilistika. Eksplorasi dan manipulasi bahasa maksudnya yaitu kemampuan pengarang dalam menggunakan dan memanfaatkan bahasa dengan maksud membalikkan suatu bahasa dan tidak mematuhi kaidah berbahasa demi tercapainya efek estetik tersebut. Keestetikan bahasa dalam puisi dapat diwujudkan melalui piranti stilistika.

Menurut Supriyanto (2011) bahasa figuratif dan citraan merupakan aspek atau piranti stilistika yang penuh dengan intensitas. Artinya, kedua aspek tersebut harus mampu membangkitkan daya imajinatif saat membaca sebuah puisi. Penyair dituntut cermat dalam memilih kata dan mempertimbangkan maknanya terlebih dahulu agar muncul efek estetik dalam larik puisi yang diproduksi. Berdasarkan hal tersebut, penelitian mengenai stilistika khususnya aspek bahasa figuratif dan citraan ini menjadi perlu dilakukan untuk mengungkap keestetikan dan simbolisasi dalam sebuah puisi.

Gaya penyampaian melalui bahasa figuratif dan citraan ini menjadi sangat penting dalam menentukan tujuan penyair mengungkapkan ekspresinya serta menjadi ciri pembeda 
dengan karya yang lain (Yono dan Mimi, 2017). Sapardi Djoko Damono melalui antologi puisi Melipat Jarak membuktikan bahwa bahasa figuratif dan citraan sangat berpengaruh dalam puisi-puisinya. Bahasa figuratif menurut Pradopo (1999) terdiri atas majas, idiom, dan peribahasa. Adapun majas dalam penelitian ini difokuskan hanya pada majas perbandingan saja, yakni simile, metafora, perumpamaan, alegori, sinekdoke, personifikasi, dan metonimia. Sementara, citraan menurut Nurgiyantoro (2014) meliputi pendengaran, gerak, penglihatan, penciuman, pencecapan, perabaan, dan intelektual.

Pemilihan bahan kajian berupa antologi puisi ini dilatarbelakangi oleh banyaknya jumlah sajak yang terangkum dalam antologi, yakni 75 puisi. Selain itu, puisipuisi Sapardi Djoko Damono juga memiliki ciri khas tersendiri jika ditinjau secara stilistika. Ciri khas itu tampak pada penggunaan bahasa figuratif dan citraan yang begitu kuat dalam setiap puisi-puisinya. Dalam puisi-puisi tersebut, tidak jarang Sapardi menggunakan diksi yang sederhana. Namun demikian, justru kata tersebut mengandung bahasa figuratif dan citraan yang mampu membangkitkan daya bayang setiap pembaca karyanya. Alasan-alasan tersebut menunjukkan bahwa karya yang diciptakan oleh Sapardi berupa antologi puisi ini memiliki keunikan tersendiri jika ditinjau secara stilistika.

Penelitian stilistika puisi pada aspek bahasa figuratif dan citraan akan lebih bermanfaat bila dilanjutkan penerapannya ke dalam pembelajaran Bahasa Indonesia di sekolah, dalam hal ini pembelajaran sastra. Dengan meneruskan penelitian ini pada pembelajaran di sekolah, harapannya dapat menambah kelengkapan materi pengayaan untuk mata pelajaran Bahasa Indonesia. Bahasa figuratif dan citraan merupakan salah satu materi pada mata pelajaran Bahasa Indonesia yang dipelajari peserta didik di sekolah. Seperti pada saat menulis puisi atau prosa, peserta didik harus dapat mempertimbangkan pilihan bahasa figuratif dan citraan yang tepat. Di samping itu, urgensi lain dari kedua aspek stilsitika tersebut dalam pembelajaran sastra adalah untuk membantu siswa agar terampil menganalisis dan menjawab soal-soal pada kegiatan latihan atau penugasan yang berkaitan dengan apresiasi puisi (Prastowo, 2013).

Penelitian yang terkait dengan aspek stilistika sebagai kajian pustaka dalam penelitian ini antara lain Pradopo (1999), Gundogdu (2012), Effendi (2013), Niazy (2013), Khan (2015), Ahmad (2016), dan Yono dan Mimi (2017). Berdasarkan penelitian terdahulu tersebut, menunjukkan bahwa penelitian mengenai stilistika puisi dan pembelajarannya memang sudah banyak dilakukan. Namun begitu, penelitian yang memiliki topik sama masih perlu dilakukan guna melengkapi khazanah penelitian di bidang stilistika dan pembelajarannya. Sementara itu, landasan teori yang relevan digunakan dalam penelitian ini adalah bahasa figuratif, majas, idiom, citraan, semiotik Riffatere, dan materi kegiatan pengayaan sastra di SMA kelas X.

Berdasarkan latar belakang dan landasan teori dalam penelitian ini, masalah yang akan dicari jawabannya meliputi, bahasa figuratif dan citraan yang dominan muncul dalam antologi puisi Melipat Jarak. Selanjutnya, pemanfaatan kedua aspek stilistika tersebut kaitannya dengan materi pengayaan sastra di SMA kelas X. Sementara itu, tujuan penelitian ini adalah untuk mendeskripsikan bahasa figuratif dan citraan yang dominan digunakan dalam antologi puisi Melipat Jarak serta memanfaatkannya sebagai simulasi sederhana kegiatan pengayaan sastra.

\section{METODE}

Penelitian ini merupakan penelitian yang menggunakan pendekatan stilistika. Pendekatan stilistika berasumsi bahwa inti atau pokok karya sastra ada dua hal, pertama adalah bahasa dan kedua yaitu isi yang berupa tema, pemikiran, dan makna (Aminuddin, 1995). Jadi, penelitian ini selain mengkaji puisi dari segi aspek stilistika juga melakukan pengungkapan terhadap makna larik puisi Sapardi Djoko Damono dalam antologi Melipat Jarak.

Proses pengumpulan data dalam penelitian ini dilakukan dengan teknik pembacaan heuristik dan studi pustaka. Teknik heuristik dilakukan dengan menerapkan pembacaan berdasarkan konvensi bahasa terlebih dahulu sambil menyimak teks puisi, kemudian mencatat data-data yang berupa bahasa figuratif dan citraan. Setelah proses pembacaan dan memperoleh data, data diklasifikasikan menurut jenisnya, yakni bahasa figuratif (majas dan idiom) dan citraan. Teknik studi pustaka digunakan untuk menemukan adanya relevansi pada aspek bahasa figuratif dan citraan dengan pemanfaatannya sebagai materi pengayaan sastra sesuai KI/KD BSNP 2013.

Analisis data yang digunakan adalah deskriptif analisis semiotik dengan metode pembacaan heuristik yang berada di tahap pertama, kemudian dilanjutkan ke tahap kedua yaitu metode hermeneutik. Metode hermeneutik dilakukan dengan memberikan makna pada tataran konvensi sastra, yakni mengaitkan larik dengan kode yang melatarbelakangi penciptaan puisi, yakni bahasa, sastra, dan lebih-lebih budaya. Selanjutnya, memberikan makna pada bahasa figuratif dan citraan yang ditemukan. Adapun untuk mencari relevansi bahasa figuratif dan citraan dalam antologi puisi Melipat Jarak karya Sapardi Djoko Damono dan pemanfaatannya sebagai materi pengayaan sastra di SMA kelas X digunakan teknik analisis komparatif dengan cara membandingkan $\mathrm{KI} / \mathrm{KD}$ yang memiliki kaitan dengan aspek-aspek stilistika tersebut.

\section{HASIL DAN PEMBAHASAN}

\section{A. Bahasa Figuratif dalam Antologi Puisi Melipat Jarak Karya Sapardi Djoko Damono}

Bahasa figuratif dalam antologi puisi Melipat Jarak karya Sapardi Djoko Damono ini dikaji dari beberapa unsur yaitu majas, idiom, dan peribahasa. Data berupa majas mendominasi antologi puisi tersebut, sedangkan data berupa idiom terbatas. Sementara itu, data berupa peribahasa dalam antologi puisi ini tidak ditemukan. 


\section{Permajasan}

Majas merupakan bahasa kias yang digunakan penulis (penyair) untuk memberi efek estetis dan mendukung terciptanya suasana serta nada tertentu dalam sebuah karya. Selain itu, majas dapat mendorong pembaca untuk menginterpretasi dan mengasosiasikan pengetahuannya terhadap suatu karya. Majas yang paling dominan ditemukan dalam antologi puisi Melipat Jarak karya Sapardi Djoko Damono secara berturut-turut, yakni personifikasi, simile, metafora.

\section{a. Personifikasi}

Majas personifikasi merupakan gaya bahasa kiasan yang menggambarkan benda-benda mati seolah-olah memiliki sifat kemanusiaan. Hal itu tampak pada kutipan berikut.

(1) "Ia tidak diberi nasi: detik pun gerah berloncatan ke sana ke mari” (MPs/SDD/9/2015)

Kutipan data (1) yang menunjukkan majas personifikasi adalah klausa detik pun gerah berloncatan. Detik digambarkan memiliki sifat layaknya manusia yaitu marah. Kemarahan detik disebabkan karena ketidakadilan yang didapatkan oleh Marsinah, si pejuang buruh. Marsinah berkorban waktu demi memperjuangkan hak-hak kaum buruh yaitu upah. Pemanfaatan majas personifikasi dalam puisi ini adalah untuk menghidupkan suasana puisi yang menggebugebu seperti perjuangan yang telah dilakukan oleh Marsinah.

Dalam puisi berjudul Dongeng Marsinah ini, upah disimbolkan dengan nasi, sedangkan perjuangan disimbolkan dengan detik yang gerah (marah). Penyimbolan upah yang digantikan dengan nasi tersebut menunjukkan bahwa tuntutan para demonstran pada waktu itu sangat sederhana, yakni kenaikan upah sebesar Rp550,-. Lain halnya apabila penyimbolan yang ditampakkan adalah hal yang menunjukkan kemewahan. Adapun penyimbolan perjuangan yang digambarkan dengan kemarahan detik merupakan keterwakilan tindakan Marsinah sebagai buruh pabrik arloji.

\section{b. Simile}

Majas yang menyamakan satu hal dengan hal lain menggunakan kata-kata pembanding seperti: bagai, sebagai, seperti, semisal, seumpama, laksana, bak, dan kata pembanding lainya adalah simile. Majas simile tampak pada kutipan berikut.

(2) "Kita ini bagai daun tua" (MS/SDD/43/2015)
Kutipan data (2) merupakan majas simile yang ditandai oleh kata pembanding bagai. Melalui kata pembanding tersebut, kata kita dibandingkan dengan frasa daun tua. Kata kita dalam puisi berjudul Ayat-ayat Api ini merujuk pada diri penulis. Penulis mengajak pembaca merenungi diri dengan cara mengandaikan dirinya seperti daun yang sudah tua. Suasana yang tercipta akibat pemanfaatan majas simile dalam puisi tersebut adalah sendu. Suasana sendu disebabkan karena perpisahan akan segera dialami oleh tokoh dalam puisi. Bukti suasana puisi menunjukkan kesenduan adalah klausa berikut, yaitu sebelum tik tok terakhir -, tapi sudahlah.

Majas simile selain berfungsi untuk menghidupkan suasana juga berfungsi untuk menghidupkan karakter atau tokoh di dalam puisi. Kata ganti kita yang merujuk kepada diri penulis diibaratkan seperti daun tua. Daun tua dalam puisi ini digambarkan dapat merasakan getaran karena terpaan angin. Hal tersebut menyiratkan bahwa tokoh dalam puisi ini dihidupkan melalui kata pembanding bagai.

\section{c. Metafora}

Majas metafora adalah majas seperti simile, hanya saja tidak menggunakan kata-kata perbandingan seperti bagai, sebagai, laksana, seperti, dan sebagainya. Berikut adalah data majas metafora yang ditemukan.

(3) "Pada suatu pagi hari seorang gadis kecil mengendarai selembar daun meniti berkas-berkas cahaya"

(MM/SDD/25/2015)

Kutipan data (3) jika dicermati ada bagian yang dilesapkan. Untuk mengetahui bagian yang dilesapkan, larik puisi diparafrase terlebih dahulu. Parafrase terhadap larik puisi tersebut menjadi pada suatu pagi hari/ seorang gadis kecil/ seperti/ sedang mengendarai selembar daun/ meniti berkas-berkas cahaya/. Frasa anak kecil dalam puisi Tiga Sajak Kecil ini diibaratkan sedang mengendarai selembar daun sambil meniti berkas-berkas cahaya. Anak kecil yang mengendarai selembar daun tersebut merupakan penggambaran lain dari anak kecil yang sedang bermain. Anak kecil tersebut menginjak-injak dedaunan dan berlarian menuju ke selatan untuk menangkap kupu-kupu. Hal tersebut ditegaskan oleh larik mau ke mana, Wuk? Ke selatan, menangkap kupu-kupu.

Majas metafora dalam puisi tersebut menciptakan suasana yang lebih hidup, yakni riang. Keriangan itu tercermin dari tingkah laku tokoh yang berlarian ke sana kemari untuk memburu kupu-kupu. Selain suasana yang hidup, majas metafora juga memberi efek deskripsi keadaan dalam puisi berjudul Tiga Sajak Kecil ini. Keadaan alam dan taman yang asri digambarkan oleh Sapardi dengan sangat unik, yaitu menggunakan perbandingan singkat seperti pada larik seorang gadis kecil mengendarai selembar daun. 


\section{Idiom}

Idiom secara prinsip mempunyai kekhasan bentuk dan makna di dalam kebahasaan yang tidak dapat diterjemahkan secara harfiah. Fungsi idiom dalam karya sastra adalah sebagai instrumen untuk mengungkapkan suatu maksud yang bertujuan untuk memberi kesan menarik. Dalam antologi puisi Melipat Jarak karya Sapardi Djoko Damono ini ditemukan data berupa idiom sebanyak 2 data pada 1 larik puisi. Berikut paparan data tersebut.

\section{(4) "Malam ini Putri Salju, kemarin Bawang Putih" (I/SDD/26/2015)}

Idiom pada data nomor (8) secara konstruksi menunjukkan nama diri atau tokoh dalam sebuah cerita. Gabungan kedua kata yang menjadi satu seperti contoh idiom pada puisi Tiga Sajak Kecil tidak mempunyai makna harfiah. Makna kedua kata itu berbeda dengan makna masing-masing kata yang menyusunnya. Makna idiom Putri Salju dan Bawang Putih baru dapat diketahui ketika seseorang membaca atau mendengar cerita tersebut. Putri Salju adalah tokoh dongeng yang berasal dari Eropa. Sementara itu, Bawang Putih juga merupakan karakter dongeng tetapi berasal dari kebudayaan lokal. Persamaan kedua cerita tersebut yakni penonjolan watak tokoh yang sama-sama protagonis. Keduanya digambarkan bersifat baik dan jauh dari watak buruk.

Berdasarkan uraian tersebut, idiom dalam puisi dapat digunakan sebagai penyimbolan atas hal-hal yang baik. Penyimbolan itu sebagai cerminan dari keseluruhan makna atau isi puisi. Selain sebagai simbolisasi, idiom dalam data puisi ini juga berfungsi untuk menghidupkan karakter atau tokoh. Penghidupan karakter dalam puisi ini mendorong pembaca untuk memanfaatkan kemampuan mengimajikan (daya bayang) terhadap larik yang dibaca.

\section{B. Citraan dalam Antologi Puisi Melipat Jarak Karya Sapardi Djoko Damono}

Pembahasan aspek citraan dalam antologi puisi Melipat Jarak karya Sapardi Djoko Damono meliputi citraan-citraan yang digunakan dalam puisi. Citraan tersebut berdasarkan yang paling dominan ditemukan antara lain citraan gerak, citraan pendengaran, dan citraan penglihatan.

\section{Citraan Gerak}

Citraan gerak sangat dominan dan produktif digunakan dalam antologi puisi Melipat Jarak karya Sapardi Djoko Damono ini. Fungsi citraan gerak adalah untuk melukiskan sesuatu yang sesungguhnya tidak bergerak tetapi dilukiskan seperti dapat bergerak atau gambaran gerak pada umumnya sehingga mampu membangkitkan daya bayang (imaji) pembaca. Berikut adalah kutipan analisis data yang termasuk citraan gerak.

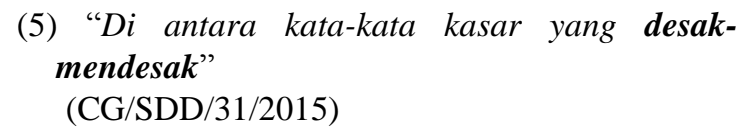

Citraan gerak tampak pada data larik puisi (5). Puisi tersebut berjudul Sonet: Entah Sejak Kapan. Citraan gerak pada kutipan di atas ditandai oleh kata ulang desak-mendesak. Kata ulang tersebut menggambarkan keadaan alam yang ada dalam puisi. Kata ulang desak-mendesak merupakan asosiasi dari sebuah keadaan yang tegang atau genting. Hal tersebut ditegaskan oleh larik awal, yakni kata-kata kasar.

Frasa kata-kata kasar menunjukkan adanya ketegangan, sementara penanda citraan (frasa desak-mendesak) pada puisi ini melukiskan kegentingan. Selain sebagai asosiasi atas peristiwa genting, citraan gerak yang direalisasikan dengan frasa desak-mendesak ini juga memiliki fungsi lain. Fungsi tersebut adalah mendorong pembaca untuk memanfaatkan kemampuan daya bayang (mengimajikan) ketika membaca larik tersebut.

\section{Citraan Pendengaran}

Citraan lain yang juga dominan dimanfaatkan dalam antologi puisi Melipat Jarak karya Sapardi Djoko Damono adalah citraan pendengaran. Citraan pendengaran berperan membangkitkan berbagai memori, peristiwa, dan pengalaman hidup yang terkait dengan pendengaran. Deskripsi dan pembahasan data citraan pendengaran tampak pada beberapa data berikut.

\section{(6) "Dan di halaman terdengar langkah-langkah bakiak almarhum neneknya" (CPd/SDD/1/2015)}

Citraan pendengaran tampak pada puisi berjudul Catatan Masa Kecil, 4. Penanda citraan pendengaran pada kutipan data (6) adalah kata terdengar. Kata tersebut menunjukkan adanya kegiatan menyimak secara lisan yang dilakukan oleh indera pendengar. Citraan pendengaran pada data tersebut mendorong pembaca agar seolah-olah ikut mendengarkan suara dan merasakan sendiri peristiwa dalam puisi.

Selain hal-hal yang telah dikemukakan sebelumnya, pemanfaatan kata terdengar dalam larik puisi berjudul Catatan Masa Kecil, 4 juga menciptakan suasana haru karena kata itu mengacu pada memori atau kenangan yang dialami oleh tokoh dalam puisi. Jadi, fungsi citraan pendengaran pada data ini terdapat dua fungsi. Pertama, mendorong timbulnya daya imaji pembaca. Kedua, berperan menciptakan suasana puisi.

\section{Citraan Penglihatan}

Selain citraan gerak dan pendengaran, citraan yang juga produktif dimanfaatkan dalam antologi puisi Melipat Jarak karya Sapardi Djoko Damono ini adalah citraan penglihatan. Citraan penglihatan umumnya berperan untuk melukiskan fisik atau karakter tokoh, latar suasana, dan tempat. Berikut adalah deskripsi data citraan penglihatan.

(7) "Dari balik tabir katarak mataku kusaksikan pinggir laut, sangat tenang" (CP1/SDD/80/2015) 
Citraan penglihatan tampak pada data (7). Data larik puisi tersebut merupakan bagian dari puisi berjudul Malin Kundang. Penanda citraan penglihatan pada data tersebut adalah klausa kusaksikan pinggir laut. Kata kusaksikan menandakan adanya kegiatan yang terkait dengan indera penglihatan. Citraan penglihatan pada data (7) memiliki peran menciptakan suasana puisi.

Suasana yang tampak pada data puisi tersebut yakni tenang. Ketenangan itu ditegaskan oleh larik setelah penanda citraan penglihatan, yaitu larik sangat tenang. Selain menciptakan suasana, citraan pada larik puisi ini juga berfungsi melukiskan keadaan tempat sekitar. Sama dengan suasana yang tercipta, latar tempat juga diimajikan dengan sesuatu yang tenang dan indah.

\section{Pemanfaatan Bahasa Figuratif Dan Citraan Dalam Antologi Puisi Melipat Jarak Sebagai Materi Pengayaan Sastra Di SMA}

Pemanfaatan kedua aspek stilistika dalam antologi puisi Melipat Jarak dapat diterapkan sebagai materi pengayaan sastra di SMA kelas $\mathrm{X}$ melalui kegiatan pengayaan eksploratori dan keterampilan proses. Berikut adalah paparan pemanfaatan aspek tersebut.

\section{Kegiatan Eksploratori}

Kegiatan eksploratori yang menuntun peserta didik mempelajari aspek bahasa figuratif dan citraan didasari oleh rumusan $\mathrm{KI} 3 / \mathrm{KD} 3.16$ dan $\mathrm{KD} 3.17$. Hal tersebut dapat dilihat dari kegiatan pengayaan melalui soal pilihan ganda dan soal isian singkat.

\section{a. Pengayaan Melalui Soal Pilihan Ganda}

Soal pilihan ganda mengenai bahasa figuratif, yakni majas dan idiom serta citraan dalam pembelajaran diberikan untuk mengukur tingkat pengetahuan atau knowledge $(\mathrm{C} 1)$ peserta didik terkait dengan seluk beluk dan pemanfaatan majas, idiom, dan citraan dalam sebuah antologi puisi. Berikut adalah contoh soal kegiatan pengayaan tersebut.

(1) Di bawah ini termasuk majas perbandingan, kecuali ....
a) majas simile
b) majas perumpamaan
c) majas metonimia
d) majas klimaks
e) majas sinekdoke

Soal (1) merupakan soal pilihan ganda untuk mengukur kemampuan pengetahuan peserta didik dalam memahami jenis-jenis majas perbandingan. Bentuk soal pilihan ganda lain untuk menilai pemahaman peserta didik mengenai pengetahuan seputar idiom dan citraan tampak pula pada soal berikut.

\section{(2) Tiga Sajak Kecil}

Pada suatu malam hari

Seorang gadis kecil menodong ibunya membaca cerita sebelum tidur;

Malam ini Putri Salju, kemarin Bawang Putih

(Damono, 2015:26)

Idiom pada larik puisi di atas adalah ....

a) Pada suatu dan malam hari

b) Seorang gadis kecil dan menodong ibunya

c) Membaca cerita dan dan sebelum tidur

d) Putri salju dan Bawang putih

e) Semua jawaban benar

(3) Citraan (imagery) yang merangsang dan membangkitkan imajinasi pembaca melalui asosiasi logika dan pemikiran merupakan ...
a) citraan gerak
b) citraan intelektual
c) citraan pencecapan
d) citraan perabaan
e) citraan pendengaran

Soal (2) dan (3) menunjukkan kegiatan pengayaan yang dilakukan untuk menguji pemahaman peserta didik kaitannya dengan memahami bentuk idiom dan jenis citraan.

\section{b. Pengayaan Melalui Soal Isian Singkat}

Seperti halnya pada soal berbentuk pilihan ganda, kegiatan pengayaan melalui bentuk soal isian singkat digunakan untuk mengukur kemampuan peserta didik di taraf yang sangat sederhana, yakni pengetahuan atau kognisi. Kemampuan pengetahuan yang diukur dengan isian singkat dalam pembelajaran stilistika antara lain kegiatan menyebutkan istilah, prinsip-prinsip serta jenis-jenis majas dan citraan. Kegiatan tersebut apabila direalisasikan dalam pengayaan melalui soal isian singkat tampak pada contohcontoh berikut.

(4) Apa yang dimaksud dengan majas metonimia?

(5) Imaji dalam karya sastra yang berperan penting untuk menimbulkan pembayangan imajinatif, membentuk gambaran mental, dan dapat membangkitkan pengalaman tertentu pada diri pembaca dinamakan ....

Soal nomor (4) dan (5) merupakan soal yang menuntun peserta didik untuk menyebutkan istilah dan salah satu jenis majas. Kata kerja operasional yang diutamakan pada soal tersebut termasuk dalam tataran pengetahuan atau kognitif, yaitu menyebutkan. Sebenarnya bentuk soal isian singkat memiliki tujuan yang sama dengan bentuk soal pilihan ganda, yakni mengukur tingkat kemampuan pengetahuan atau kognitif dasar. Akan tetapi, dengan diberikannya bentuk- 
bentuk soal yang berbeda memunculkan variasi, jenis, dan bentuk alternatif soal lain meskipun bertujuan sama.

\section{Kegiatan Keterampilan Proses}

Dalam pembelajaran stilistika di SMA, khususnya yang berkaitan dengan aspek bahasa figuratif dan citraan, keterampilan proses yang relevan dengan kegiatan tersebut didasari oleh KI 4/ KD 4.17, yakni menulis puisi dengan memerhatikan unsur-unsur pembangunnya. Kegiatan pengayaan yang dilakukan untuk meningkatkan keterampilan proses biasanya adalah memberikan perintah melalui bentuk soal uraian atau essay. Berikut adalah contoh soal untuk kegiatan tersebut.

\section{(6) Sajak Tafsir}

\section{...}

Aku sungai, yang hanya bisa mengikat pohon yang mengambang bersama cahaya sore di sela-sela awan yang kadang-kadang juga kautafsirkan sebagai lambang kefanaan

(Damono, 2015:68)

Analisislah kutipan puisi di atas berdasarkan aspek berikut:
a) majas,
b) citraan,
c) suasana, dan
d) makna yang terkandung dalam puisi tersebut.

Contoh soal (6) adalah salah satu bentuk kegiatan pengayaan yang mengukur keterampilan peserta didik dalam menganalisis dan memaparkan unsur-unsur pembangun dari sebuah puisi. Contoh tersebut memiliki tingkat kompleksitas yang lebih jika dibandingkan dengan contoh soal pilihan ganda maupun isian singkat. Melalui soal tersebut, diharapkan keterampilan proses berupa kemampuan analitis akan terpupuk pada diri peserta didik.

Selain memupuk kemampuan analitis, kemampuan proses juga bertujuan untuk meningkatkan kemampuan memproduksi karya, yakni menulis puisi berdasarkan unsur pembangunnya. Hal tersebut tampak pada contoh soal berikut.

(7) Buatlah sebuah puisi bertema bebas dengan memperhatikan unsur-unsur pembangun sebuah puisi!

Contoh soal nomor (7) merupakan soal yang menuntun peserta didik untuk meningkatkan keterampilan proses dalam menulis puisi. Keterampilan ini membutuhkan kemampuan yang lebih kompleks karena harus mengimplementasikan pengetahuan mengenai aspek stilistika yang sudah dipahami agar menjadi sebuah puisi.

Berdasarkan contoh-contoh soal dan materi pengayaan tersebut ada dua manfaat yang dapat diambil dalam kegiatan pengayaan ini. Pertama, keterampilan eksploratori akan semakin terasah karena peserta didik akan menerapkannya ketika menulis puisi. Kedua, kemampuan menulis puisi secara otomatis juga akan meningkat.

\section{SIMPULAN}

Pengkajian stilistika aspek bahasa figuratif dan citraan dalam antologi puisi Melipat Jarak karya Sapardi Djoko Damono ini menghasilkan tiga simpulan, yakni 1) bahasa figuratif yang muncul dalam antologi puisi Melipat Jarak adalah majas dan idiom. Pengkajian terhadap majas dibatasi hanya pada majas perbandingan saja. Majas yang dominan muncul adalah majas personifikasi, simile, dan metafora. 2) Citraan yang dominan ditemukan dalam antologi puisi Melipat Jarak, yaitu citraan gerak, citraan pendengaran, dan penglihatan. 3) Kedua aspek stilistika tersebut dapat dimanfaatkan sebagai materi kegiatan pengayaan. Pengayaan tersebut dilakukan dalam dua kegiatan. Pertama, kegiatan eksploratori. Kegiatan ini meliputi pengayaan melalui soalsoal berbentuk pilihan ganda dan soal isian singkat. Kedua, kegiatan keterampilan proses. Kegiatan keterampilan proses diberikan melalui soal-soal yang berbentuk uraian atau essay.

\section{DAFTAR PUSTAKA}

Ahmad, Zaheer. 2016. "Use of Symbols \&Classical Allusions in Hamlet". Journal of Literature, Languages, and Linguistics. Vol. 20, 2016.

Al-Ma'ruf, Ali Imron. 2009. Stilistika: Teori, Metode, dan Aplikasi Pengkajian Estetika Bahasa. Surakarta: Cakra Books.

Effendi, dkk. 2013. "Kemampuan Menentukan Citraan Puisi Karya Sapardi Djoko Damono pada Siswa SMP”. Jurnal Kata: Bahasa, Sastra, dan Pembelajarannya. Vol. 1 (2) hal. 23-34.

Gundogdu, Ayse Eda. 2012. "A Stylistics Analysis Of Haldun Taner's Story: Konçinalar”. Jurnal Adiyaman University International Journal of Social Science. Vol. 5 (8) hal. 42-56.

Khan, et all. 2015. "Stylistic Analysis of the Short Story 'The Last Word' by Dr. A. R. Tabassum”. Jurnal Advances in Language and Literary Studies. Vol. 6 (3) hal. 1123.

Niazy, Nozar. 2013. “A Stylistic Analysis of D.H. Lawrence's 'Sons and Lovers"'. Jurnal International Journal of Applied Linguistics \& English Literature. Vol. 2 (4) July 2013.

Nurgiyantoro, Burhan. 2014. Stilistika. Yogyakarta: Gadjah Mada University Press.

Pradopo, Rachmat Djoko. 1999. "Penelitian Stilistika Genetik: Kasus Gaya Bahasa W.S. Rendra dalam "Balada Orang-orang Tercinta dan Blues untuk Bonnie" dalam Jurnal Humaniora Nomor 12, Tahun 1999. 
Prastowo, Andi. 2013. Panduan Kreatif Membuat Bahan Ajar Inovatif. Jogjakarta: Diva Press.

Supriyanto, Teguh. 2011. Kajian Stilistika dalam Prosa. Yogyakarta: Elmatera.

Yono, Robert dan Mimi Mulyani. 2017. "Majas dan citraan dalam Novel Kerling Si Janda Karya Taufiqurrahman Al-Azizy" dalam Jurnal Seloka Vol. 6 (4), Tahun 2017. 